\title{
Applying the Values of Geoethics for Sustainable Speleotourism Development
}

\author{
Aleksandar Antić ${ }^{1}$ - Silvia Peppoloni ${ }^{2,3} \cdot$ Giuseppe Di Capua ${ }^{2,3}$ \\ Received: 23 April 2020 / Accepted: 29 July 2020 / Published online: 25 August 2020 \\ (C) The Author(s) 2020
}

\begin{abstract}
Establishing sustainable and responsible speleotourism development is a major challenge and involves complex activities. Adequate theoretical starting point is the application of geoethical values related to the conservation and protection of the caves to be used for touristic purposes. Positive and negative cases of human behaviors towards speleological geoheritage are discussed, in order to highlight what should be done in cave management to avoid malpractices and on what elements could be founded adequate strategies aimed at promoting sustainable speleotourism. This is important to tourism management organizations involved in the promotion of caves and in creating economic opportunities for local populations, while respecting cave ecosystems. Modern cave management must be focused on the protection of the cave ecosystems, finding ways to achieve at the same time an economic development of local communities. But this approach needs the adoption of a geoethical framework of values to be shared by all stakeholders involved so that successful cooperation can be achieved despite differences in interests and expectations. The aim of this paper is to raise the awareness about the need to apply the values of geoethics to speleotourism, stimulating new fields of discussion within the scientific and technical communities involved in studies and activities related to geotourism and geoheritage. The possibilities of developing new ways to manage caves, in order to promote a sustainable socioeconomic development of local communities, have to be balanced with the protection of natural environments as much as possible. The proposed theoretical frameworks have the goal to increase the discussion on the best ways of connecting speleotourism to sustainable and responsible cave management, presenting two case studies, and pointing out potential solutions.
\end{abstract}

Keywords Geoethics $\cdot$ Responsibility $\cdot$ Sustainability $\cdot$ Caves $\cdot$ Speleotourism

\section{Introduction}

Sustainable forms of tourism development refer to touristic activities that minimize negative impacts on the environment, have positive repercussions on social communities, local economy (Romelić and Tomić 2002), and management of

Giuseppe Di Capua

giuseppe.dicapua@ingv.it; https://www.geoethics.org

Aleksandar Antić

a.antic994@gmail.com

1 Faculty of Sciences, Department of Geography, Tourism and Hotel Management, University of Novi Sad, Trg Dositeja Obradovića 3, Novi Sad 21000, Serbia

2 Istituto Nazionale di Geofisica e Vulcanologia, via Vigna Murata 605, Rome 00143, Italy

3 International Association for Promoting Geoethics, Rome, Italy natural sites and resources, which often are the main interest of tourists and excursionists for a specific area (Newsome et al. 2012). The growing global need to use natural environments for touristic purposes requires a sustainable approach to manage natural sites, and quality management strategies should be implemented especially in very sensitive areas, such as regions with rich geodiversity.

Geodiversity represents the natural range of geological, geomorphological, soil, and hydrological features (Gray et al. 2013) and it is a crucial aspect of geosystem services that bring cultural, educational, and social benefits to the society (Gray 2018; Gray 2019). A sound knowledge of geodiversity is an important factor in the holistic approach for sustainable tourism development (Newsome and Downling 2018), but it is also highly relevant to the wider nature conservation agenda (Gordon 2020). In addition to sustainable (geo)tourism development, the geoconservation, protection, and continuous sustainability should be the goal of geoheritage management structures. Geoconservation 
includes the protection of geoheritage features and geosites (Gordon 2020), allowing geosystem to support numerous services that provide human well-being through ecosystems (Brilha et al. 2018). Furthermore, the efficiency of conservation management can have social and ecological outcomes on geosites and bring prosperity to people living near protected areas (Abukari and Mwalyosi 2020).

Cave tourism, i.e., speleotourism, is a type of tourists' movement within speleological objects, which include tourist interpretation of speleological and hydrological geoheritage, biodiversity, as well as anthropogenic factors, speleo-archeological artifacts, and cave paintings (Cigna 1993). Numerous examples of using speleotourism with significant economic returns can be found around the world, like Postojna Cave in Slovenia and Mammoth Cave in the USA (Tičar et al. 2018). Nevertheless, implementing carefully strategies for sustainable development are necessary to achieve a balance between tourism development and ecological protection of the cave systems (Tomić et al. 2019). This should be applied to all geoheritage sites, but in the case of karst geosites, such an approach is crucial for maintaining their delicate geological features and ecosystems, due to the level of fragility existing inside caves (Lobo et al. 2013).

The idea of conservation and management of karst sites is particularly important for cave protection, in the perspective of speleotourism development. Karst resources need to be managed because of their relative rarity, the high recreational demands, and the fragility and vulnerability of features found in karst areas. The importance of karst management and (show)cave protection strategies is a prerequisite for the utilization and development of various forms of speleotourism (Parise 2011). Whether it is developed speleotouristic sites with high tourist traffic or caves with national or regional significance without touristic impact, it is necessary to carry out a wide range of activities in order to achieve the sustainability of speleotourism development. First and foremost, continuous monitoring of caves and the implementation of an appropriate carrying capacity strategy should be implemented (Lobo 2015), in order to maximize the protection of all valuable elements found in caves. An all-in strategy requires also of applying values of geoethics (Peppoloni et al. 2019) that can significantly influence the responsible management of caves and other geosites and their protection.

Tourism management of caves should depend on their types. Caves or parts of them that are active and have a high-energy environment, such as those with high water flow, are much less sensitive to internal changes caused by humans. However, the presence of humans in a cave with a low energy environment, and/or the simple placement of an entrance door, can much alter the temperature and humidity regime (Freitas 2010). Therefore, it is necessary to carefully consider the tourist arrangement of the caves and devices used. Prior to the decision to design the cave for touristic visits, a series of detailed multidisciplinary analyses should be carried out, in order to establish an adequate strategy aimed at speleotourism purposes. Many anthropogenic impacts on caves are cumulative and often lead to irreversible degradation of cave ecosystems. Additional emerging issues relate to the feasibility and cost of monitoring, frequency of replication and measurement, quality control, data analysis plan, management standards, and impact indicators.

Ensuring sustainable speleotourism means guaranteeing the prolonged use of a speleotouristic geosite over time, and this implies the capability of assuring also its conservation. This requires a cultural change that can lead to consider a speleotourism site as a social, economic, and cultural resource, as well as economic, of a given territory. To achieve this, it is necessary to put in practice geoethics values (Peppoloni et al. 2019) to speleotourism. Geoethics can significantly influence the responsible management of caves and other natural sites. The lack of literature focusing on connections linking geoethics, geoheritage, and geotourism (and in a more specific case, speleotourism) makes this article a novelty in the field and a way to provoke new insights into the relationships between ethical aspects affecting responsible cave management.

\section{Geoethics: Definition and Content}

Since ethics concerns the rightness and wrongness of human behaviors related to a given circumstance that implies a choice by the agent, it is linked to all human activities while impacting the Earth system. In the last few years, special attention has been given to geoethics, an emerging field in geosciences, and in 2012, the International Association for Promoting Geoethics (IAPG - http://www.geoethics.org), a scientific and multidisciplinary network for developing and spreading geoethics, was founded. Today, this NGO has more than 2500 members in 129 countries on five continents. Its main goal is to widen the discussion and create awareness about ethical issues that arise in conducting activities in different fields of geosciences. Issues such as management of geo-resources and georisks, promotion of geoeducation and geosciences communication towards society, climate change and ocean science studies, and global and local changes of socio-ecological systems have many ethical and social repercussions, of which geoscientists are not sufficiently aware, and even more the society. In addition, the IAPG highlights the ethical and societal relevance of geoheritage and geodiversity and the necessity to enhance and protect them at the same time.

The existence of such a scientific association enables numerous scientific organizations and institutes to participate in the global plan for emphasizing the importance of geoethical 
thinking not only within the scientific community but also in the society as a whole.

The theoretical frameworks of geoethics have been analyzed in a large number of scientific publications (Bohle 2019; Peppoloni and Di Capua 2012, 2015, 2017, 2018; Peppoloni et al. 2015; Bobrowsky et al. 2018; Gundersen 2018; Wyss and Peppoloni 2015). The most comprehensive definition of geoethics is provided by Di Capua and Peppoloni (2019):

(Geoethics) Consists of research and reflection on the values which underpin appropriate behaviours and practices, wherever human activities interact with the Earth system. Deals with the ethical, social and cultural implications of geoscience knowledge, research, practice, education and communication, and with the social role and responsibility of geoscientists in conducting their activities. Encourages geoscientists and wider society to become fully aware of the humankind's role as an active geological force on the planet and the ethical responsibility that this implies. Is considered a point of intersection for Geosciences, Sociology, Philosophy and Economy

This definition clearly shows the strong link between ethics, geosciences, and human activities and proposes the concept of geoheritage as a social value to promoted among citizens (Peppoloni and Di Capua 2016; Peppoloni et al. 2019). Therefore, also in the case of speleotourism development, it is necessary to consider geoethical values and responsibilities involved in the management of caves, in order to maximize their protection and guarantee their enjoyability for the future.

\section{Values and Responsibilities in Geoethics}

Studying the interrelationships existing in geosciences requires the integration of multidisciplinary approaches and different skills and methods to address complex issues. Modern science requires that professional scientists work in multidisciplinary teams. Responsible scientists understand the importance of sharing the results of their research properly and appreciate the importance of transferring their scientific knowledge to society. Sharing data and ideas with colleagues, decision-makers, and citizens can open the way to valuable and functional relationships that will benefit the humanity and the planet. Geoethics stresses responsible conduct and cooperation in geosciences (Bobrowsky et al. 2018; Mogk 2017; Peppoloni et al. 2015). Geoethics can orient towards best or at least more acceptable choices that arise from careful analyses of pros and cons for a certain circumstance, aiming to find a balance between environmental protection and human needs, in the long-term perspective of guaranteeing sustainability to socio-ecological systems.

For these reasons, considering some values to be considered a common reference framework in problem-solving becomes indispensable. Individual values such as honesty, awareness, reliability, and competence, together with social values such as safety, cooperation, prevention, adaptation, education, and cultural values such as conservation of geological landscapes, geodiversity, and geoheritage are fundamental for a sustainable management and development of speleotourism activities.

The geoscientist is the core of an ethical reference system in which individual, professional, social, and environmental values coexist. Geoethics refers to the correctness and the benignity of the individual behaviors of the scientist as well as to his/her behaviors towards colleagues in terms of integrity and professionalism, but it also includes aspects of responsibility towards society and the environment and more in general the Earth system (Bobrowsky et al. 2018; Peppoloni et al. 2019). Geoscientists can act at various scales, and therefore, they have to deal with these diverse ethical levels of interactions. The goodness of behaviors is best measured based on common values. These values refer to four geoethical domains: individual, inter-personal/professional, societal, and environmental (Peppoloni et al. 2019). In the individual domain, the value and benefits of research and technological implementations vitally depend on the honesty and integrity of scientists, and personal skills and abilities, which have to be developed, strengthened, and maintained at a high level of competence and professionalism. The inter-personal/professional domain refers to the relationships between colleagues, to the management of multidisciplinary research and professional practices, and to the internal relationships between individuals and hosting research institutions, academia, or professional bodies. The societal domain comprises responsibilities for the communication and dissemination of data and findings, education of citizens and their direct involvement in scientific and technological activities, duties towards general public, decision-makers, local authorities, and industry. The environmental domain refers to the interaction between scientific and technological activities and the natural environment, both in its biotic and abiotic elements, in the awareness that scientists have to approach the Earth system by protecting as much as possible its geodiversity and biodiversity, and by adopting innovative strategies and technologies in order to avoid contributing to the irresponsible depletion of its resources and irreversible alterations of ecosystems (Di Capua et al. 2018; Peppoloni et al. 2019).

Geoscientists have adequate knowledge, expertise, and professional and cultural sensibilities to help protecting natural environments, preventing society from georisks, managing natural resources (minimizing negative impacts on 
ecosystems), and enhancing scientific, educational, cultural, and esthetic values of geodiversity and biodiversity, also for assuring to future generations the right to enjoy the richness and beauty of ecosystems. But this requires a responsible approach to profession and introducing a geoethics training in university curricula (Bobrowsky et al. 2018; Mogk and Bruckner 2020).

\section{Sustainable Speleotourism}

Sustainable tourism results in the management of resources in order to meet all economic, social, and esthetic needs, while preserving cultural integrity, basic ecological processes, biological diversity, and life-support systems. As indicated in Stamenković and Lutkić (2008), sustainable tourism should:

1. Make optimal use of resources, helping to conserve natural heritage and biodiversity;

2. Respect the socio-cultural authenticity of the local human communities to protect their cultural heritage and traditional values, and;

3. Ensure sustainable long-term business, generating economic benefits as a contribution to poverty reduction.

Visiting the caves is one of the significant forms of tourism. Speleotourism flourished in the early 1980 s, when it was reported that 26 million people visited caves around the world (Cigna 2016). By analyzing the available literature in the field of sustainable tourism and speleotourism (Tomić et al. 2002; Antić 2018; Tičar et al. 2018; Font et al. 2019; Hall 2019; Nepal et al. 2019; Tomić et al. 2019; Vuković and Antić 2019), it can be concluded that the main objective of sustainable speleotourism would be to establish a healthy cave ecosystem, which fosters the co-presence of geomorphological, hydrological, biological, and anthropogenic factors and produces economic results for the local population.

Speleotourism includes visits to underground caves and similar geomorphological features. An important aspect of the attractiveness of caves lies in the subjective experience of every individual (Kim et al. 2008; Liso et al. 2020). However, the presence of visitors can bring some negative aspects, which can have consequences for the bio- and geoenvironment of caves. The most common threat to the esthetic and natural state of caves is garbage disposal and graffiti writings. The responsible management of the caves in the light of a geoethical perspective can bring to their protection, but it requires a professional approach and financial support, in order to assure sustainability to those valuable sites.

Caves are often in the focus of geoscientists. Stalagmites are increasingly being used for paleoclimate research. Because the number of stalagmites in a cave is finite, sampling conflicts with cave conservation, especially for caves containing few speleothems. Therefore, the sampling strategy must be selective and trying to reach a compromise between the scientific goal and cave conservation issues (Baeza et al. 2018). Achieving sustainability with speleotourism is essential, but it requires numerous considerations both in the fields of tourism development and scientific studies.

One of the initial steps towards the protection of a cave is the establishment of cave-security systems. Electronic technology makes it possible to establish secure systems in caves. Setting alarms and surveillance equipment (cameras) can additionally provide security and prevent potential vandalism. Light, vibration, and magnetic sensors can distinguish between humans, bats, and other animals, suggesting that their application is extremely practical (Elliott 2004).

Audible alarms are most prevalent in the USA (Elliott 2004). However, using them can annoy animals that may damage the equipment. A silent alarm would alert only the authorities who could arrest or warn vandals.

There are many options for implementing security systems, among them light detectors, infrared light rays, motion detectors, vibration detectors, magnetic detectors, and infrared flash cameras. All these sensors can be connected to a system that transmits information from the cave, either through a cable or through wireless networks. The system may then initiate an automated telephone call, radio call, or satellite signal to the competent authority. Covert video and cameras are routinely used to obtain evidence, leading to the arrest and conviction of lawbreakers (Elliott 2004).

\section{With and Without the Values of Geoethics}

\section{The Case Study of Gabrovnica Cave (Eastern Serbia)}

A unique example that can be distinguished as a representative act of vandalism towards speleological geoheritage is the carving on cave paintings in a small cave of Gabrovnica, in Eastern Serbia (Fig. 1). The cave is located on the left bank of the Trgovište Timok river, nearby the village of Gabrovnica (close to the town of Knjaževac), only $10 \mathrm{~m}$ from the road, but it is almost impossible to see because the entrance to the cave has grown into thorns and shrubs. The cave painting is vertical and is located at the entrance. It is the only recorded example of cave paintings in Serbia, discovered in 1997 during the research conducted jointly by the Faculty of Philosophy in Belgrade and the local museum. It is assumed that cave art relates to the end of the Bronze Age and the beginning of the Iron Age (Mihailović and Jovanović 1997). The ruined painting is the most significant and visible one of several in the cave. The drawing represents a horse with a rider and is done in black color. Physical damage was done by using a sharp object. Figure 1 shows the appearance of a cave painting before and after the vandalic act. The damage is evident and 
Fig. 1 Ruined drawing in a cave in Eastern Serbia; a before the act of vandalism; $\mathbf{b}$ after the act of vandalism that jeopardized the prehistoric drawing (authors' own)
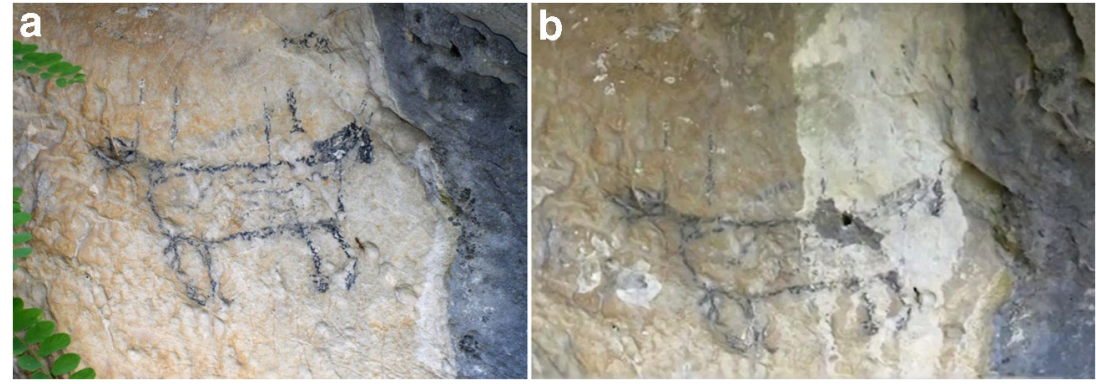

devastating. Such incidents occur due to the lack of adequate care of the caves and the absence of responsible behaviors by some people towards them, since they are not capable to appreciate the cultural value and the significance of maintaining this ancient trace of human civilization for current and future generations. A society in which the values of geoethics are known and with people more aware of their importance can substantially reduce the possibility of such acts repeating, and it can directly influence the maintenance of all scientific and tourist advantages of the caves. Geoethics instills respect for geological heritage and geodiversity, as well as highlights the importance of preserving the value of natural places in a territory as a fundamental element of the identity of local population, indispensable witness of a continuous interaction of humans with the land in which live, and potential source of economic, cultural, and social development of the community.

From a geoethical perspective, it is necessary to implement the following two measures of conservation, in order to improve the condition of this cave towards a more responsible use:

- Involving local NGOs to create tours to visit ancient drawings,

- Educating the local population on the importance of those drawings to understand human cultures and history.

\section{The Case Study of Lascaux Cave (Southern France)}

Adequate implementation of a geoethical approach to cave management can be seen in the Lascaux Cave (Southern France). Although this cave cannot be compared with the cave in Serbia in terms of cave paintings by any parameters, it is necessary to emphasize the difference in their approach of organizational and managerial structures.

The Lascaux Cave, located in the Dordogne department in France, is considered to be one of the most important prehistoric caves in the world, containing some of the best-known Upper Paleolithic art, and is included in the list of UNESCO World Heritage Sites (Xu et al. 2015).
The green biofilm and other deteriorations linked to tourism led to the closure of this cave in 1963. This damage was attributed to alterations induced by visitors' breath and the lighting which favored microbial and algal growth (Bastian and Alabouvette 2009). In order to assuage the public's substantial disappointment, the French government set about creating a facsimile copy of the original cave named Lascaux II. A second minor evolution occurred with the construction of a partial replica of Lascaux by Jean François Tournepiche in 1993 (Fig. 2). This new replica was named Lascaux 2.5. The next stage in the evolution of Lascaux came about with the construction of a virtual reality version. This project was headed by the American electronic artist and academic, Benjamin Britton (Wilken 2005). Although this approach is the result of an imposing Paleolithic heritage, it is necessary to point out the quality measures being implemented that have had the goal to protect and conserve the natural integrity of the cave and its humans' drawings, creating the possibility to admire this precious heritage of human culture through alternative means, including modern technologies, a smart way to find a balance between nature and archeological conservation and fruition for touristic purposes. This could be considered a positive case of applying geoethical values in managing a cave that suffered damages from overtourism.

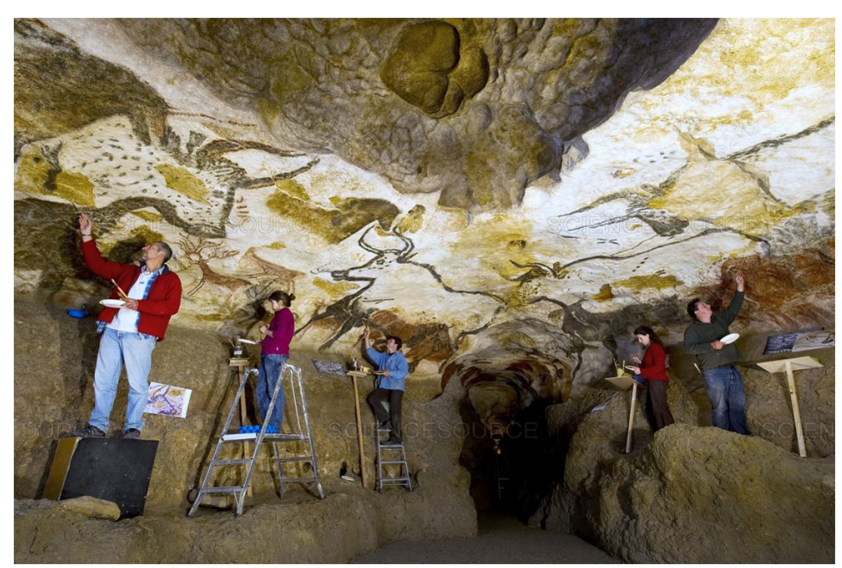

Fig. 2 Artist restoring Lascaux Cave paintings replica. Source: (sciencesource.com) 


\section{Results and Discussion}

The application of the geoethics values to caves management can have very positive implications, which can prevent the degradation due to anthropogenic factors. After reviewing both theoretical aspects of geoethics and its practical application, as well as the theoretical framework of speleotourism, it is necessary to efficaciously integrate all the activities into the light of those values. The theoretical framework of speleotourism is crucial for determining the goal of speleotourism development, which is economic profit, reduction of unemployment, respect for natural environments and its dynamics, and sustainable development of the local human community.

Theoretical research clearly points three principles, which are crucial for the sustainable management of caves for touristic purposes, namely:

1. Monitoring (tourist arrangement and maintenance of the cave ecosystem).

2. Educating to geoethics values (geoheritage and geodiversity protection, local population inclusion and cooperation, enhancement of sense of place as an element of cultural identity of people).

3. Implementing solutions to develop speleotourism programs (establishing quotas of people visiting the cave, organizing educational paths to explain the importance and delicacy of cave's ecosystem, including the possibility to involve young people in activities of citizen science, creating links with local museums to attract people into touristic tours within the territory in which the cave is located, etc.).

Environmental quality monitoring of the cave should determine the optimum range of temperature and humidity, as well as the permissible level of carbon dioxide, in order to avoid chemical and biological alteration of the delicate geoand ecosystems within the cave. The cave monitoring is important to assess the impact of human activity inside and outside the cave (changes in the surrounding winter ground or basin), identify the local climatic changes and trends that can affect the cave ecosystem, and control the cave's microclimate (Day and Koenig 2016), with the final goal to provide a responsible and sustainable cave management. Due to the fact that caves are very sensitive and under constant pressure, the following monitoring priorities should be set up:

1. Preserving biotic communities;

2. Conserving abiotic resources;

3. Establishing a healthy cave ecosystem (to be defined by microclimate indicators);

4. Limiting the presence of humans, according to the calculated values of the carrying capacity of the cave;
5. Ensuring the integrity of the cave, as a natural laboratory for multidisciplinary scientific research (Day and Koenig 2016).

Adequate speleotourism development requires the implementation of quality development strategies and a wellprepared accompanying program. In particular, speleotourism development needs the intersectoral linking and engagement of stakeholders, such as business owners, scientists and scientific institutes, educational institutions, speleological and mountaineering organizations, political organizations, investors, and local authorities. A good cooperation between all these different components will be ensured by the awareness that each of them is working to achieve a common goal, namely the protection of a common resource for that territory.

The initial steps towards modernizing and improving speleotourism should include the following:

- Establishing a unique national association for the maintenance, promotion, and development of speleotourism.

- Strategic linking with local and national authorities.

- Fostering educational activities on the importance of geodiversity and biodiversity based on geoethical values.

- Mapping caves that could equipped for touristic purposes, after scientific studies, with state-of-the-art systems and instruments.

- Modernizing interpretative tables and signs for all touristic caves.

- Establishing geoparks or karst parks, and including cave sites into a touristic route.

- Developing active and constant observation of the microclimate of each cave, the impact of tourists, and the maintenance of ecosystems using the concept of carrying capacity.

- Continually analyzing potential caves for tourism development.

Active education, at all levels, the organization of seminars, congresses, conferences, and other forms of scientific promotion of caves, is crucial for nurturing knowledge of speleology and speleotourism. The value of karst and the multidisciplinary study of caves further confirms the need for permanent protection of karst regions. From a natural point of view, karst regions are very vulnerable natural systems that may suffer degradation in consequence of many human actions; hence, their protection is of great importance (Parise and Pascali 2003). However, karst regions possess economic significance, due to their capability to form attractive geological sites that can be in the focus of many potential visitors, by guaranteeing a balance between conservation and tourism development.

The involvement of young geoscientists and students as volunteers should be also considered for the purpose of 
photographing, documenting, and then carefully removing graffiti, garbage, and other factors resulting from unethical behaviors. This can lead to the establishment of summer schools and science camps in order to train them on appropriate methods and techniques. Before restoring the cave to a more natural state, it is necessary to consider how much the cave has been altered and to define the realistic objectives of restoration projects. In order to start planning projects, the following questions should be answered:

- How well do we know the cave ecosystem? (animal species, their numerical status, microclimate, variability of physical, chemical, and biological parameters in the cave);

- How can we restore the cave to a more normal esthetic and ecological state without causing additional damages?

The task of the cave manager is to bring together all parties interested in the scientific, cultural, and recreational use of the caves in order to find a reasonable alignment of needs, benefits, interests: the conservation of the cave's ecosystems and natural environment, economic profit, and the involvement of local residents in the tourism development.

Every showcave or open cave site has different geological and sedimentological features, archeological elements (if any), and ecological systems. This needs to be considered when applying geoethical practices to manage those sites, in order to take care of geodiversity, biodiversity, and cultural diversity of each cave. All aspects of speleological exploitation for tourist, scientific, or economic needs must include the application of geoethical values and use an adequate sustainable strategy that can provide future generations with a wellpreserved speleological heritage.

Furthermore, the global health crisis is crucially affecting any development in terms of tourism. Therefore, it is important to establish all preventive measures, in order to provide visitors with a safe tourist experience. Firstly, it is necessary to provide them with masks, gloves, and disinfectants. Secondly, limiting the number of visits to the caves accordingly to the regulations prescribed by governments and/or local authorities.

\section{Conclusion}

Conducting environmental quality cave monitoring is a very complex activity, requiring careful consideration of a large number of indicators. Before implementing any monitoring strategy, it is necessary to investigate the speleomorphology and cave ecosystems, to define the monitoring objectives and to cooperate with organizations that will fund the project for using the cave. Practice shows that these are time-consuming processes, which often involve a great deal of effort.
Given that caves represent a non-renewable natural resource, responsible and professional behaviors by all stakeholders should be applied, in order to minimize anthropogenic impact, maximize protection, and develop an ecosystemfriendly management. Applying values of geoethics can contribute to the cave protection, ensuring benefits to local population in the short term, and to future generations in the long term. Therefore, geoethics brings a variety of advantages to cave management and speleotourism activities, as it recalls all societal stakeholders to a responsible approach in problemsolving as a crucial pillar to guarantee a sustainable development to economy, a balance between commercial operation and sustainable tourism as an indispensable, modern strategy to be adopted by cave operators. Responsible speleotourism has the potential (a) to reduce unemployment in local communities, (b) to foster the protection of natural environments, since those environments, if properly managed, can be also protected through adequate legal frameworks and not left to carelessness and acts of vandalism, and (c) to attract new investments that can be used for increasing the richness of population and fund activities capable to increase the means for and the quality of caves' protection. We are aware that many showcaves in the world have been still operating for decades, so introducing new methodologies in their management would mean a complete business restructure and changes of entrances/exits, lighting, and external buildings that are in place from many years may be very costly. And guidance should be considered for previous businesses; otherwise, much of today's current speleotourism would not assure adequate standards for sustainable activity. It should also be noted that many historically operating showcaves and cave sites' ecosystems may have already been altered due to visitor flows, temperature, and external cave lighting which in turn affects the flora and fauna of the cave (for example hightemperature lighting can create lampenflora as well as increase the temperature of the cave which in turn can alter the cave ecosystem).

Some showcaves and cave sites are run by local authorities and therefore adequate amounts of funding are available to introduce new measures for conservation and cave protection. This may become more difficult for private businesses to ascertain - particularly in regard to approaches such as capacity restrictions, as many private businesses may rely on large capacities.

But, introducing new business models and management strategies is a necessity if we want to enhance a geoethical approach to speleotourism, capable at the same time to improve the local economy, sustain communities, protect geoheritage, and enjoy the beauty of nature.

Acknowledgments The authors wish to thank the anonymous reviewers for their constructive and useful comments and suggestions. 
Funding Information Open access funding provided by Istituto Nazionale di Geofisica e Vulcanologia within the CRUI-CARE Agreement.

Open Access This article is licensed under a Creative Commons Attribution 4.0 International License, which permits use, sharing, adaptation, distribution and reproduction in any medium or format, as long as you give appropriate credit to the original author(s) and the source, provide a link to the Creative Commons licence, and indicate if changes were made. The images or other third party material in this article are included in the article's Creative Commons licence, unless indicated otherwise in a credit line to the material. If material is not included in the article's Creative Commons licence and your intended use is not permitted by statutory regulation or exceeds the permitted use, you will need to obtain permission directly from the copyright holder. To view a copy of this licence, visit http://creativecommons.org/licenses/by/4.0/.

\section{References}

Abukari H, Mwalyosi RB (2020) Local communities' perceptions about the impact of protected areas on livelihoods and community development. Glob Ecol Conserv, e00909

Antić A (2018) Speleotourism potential and tourist experience in Resava cave. Menadžment u hotelijerstvu i turizmu 6(2):61-69

Baeza E, Lozano RP, Rossi Nieto C (2018) Replication and reinsertion of stalagmites sampled for paleoclimatic purposes. Int J Speleol 47(2): 137-144

Bastian F, Alabouvette C (2009) Lights and shadows on the conservation of a rock art cave: the case of Lascaux Cave. Int J Speleol 38(1):6

Bobrowsky P, Cronin V, Di Capua G, Kieffer S, Peppoloni S (2018) The emerging field of geoethics. In: Gundersen LC (ed.) Scientific integrity and ethics: with applications to the geosciences. Special Publications 73. Washington, DC: American Geophysical Union; Hoboken, NJ: John Wiley and Sons, Inc

Bohle M (Ed.) (2019) Exploring geoethics: ethical implications, societal contexts, and professional obligations of the geosciences. Palgrave Pivot, Cham, XIV + 214

Brilha J, Gray M, Pereira DI, Pereira P (2018) Geodiversity: an integrative review as a contribution to the sustainable management of the whole of nature. Environ Sci Pol 86:19-28

Cigna AA (1993) Environmental management of tourist caves. Environ Geol 21(3):173-180

Cigna, A. A. (2016). Modern trend in cave monitoring. Acta carsologica, 31(1)

Day M, Koenig S (2016) Cave monitoring priorities in Central America and the Caribbean. Acta Carsologica, 31(1)

Di Capua G, Peppoloni S (2019) Defining geoethics. Website of the IAPG - International Association for Promoting Geoethics. http:// www.geoethics.org/definition. Accessed 13 July 2020

Di Capua G, Peppoloni S, Haslinger F, Marti M (2018) Ethical guidelines for RIs. Deliverable 13.3, ENVRIplus project. http://www. envriplus.eu/wp-content/uploads/2019/05/D13.3 Ethicalguidelines-for-RIs.pdf. Accessed 13 July 2020

Elliott WR (2004) Protecting caves and cave life. Encyclopedia of Caves (eds Culver DC, white WB). Elsevier academic press, Amsterdam, 428-467

Font X, Higham J, Miller G, Pourfakhimi S (2019) Research engagement, impact and sustainable tourism. J Sustain Tour 27(1):1-11

Freitas CR (2010) The role and importance of cave microclimate in the sustainable use and management of show caves. Acta carsologica 39(3)

Gordon, J. E. (2020). Geoconservation principles and protected area management. International Journal of Geoheritage and Parks
Gray M (2018) The confused position of the geosciences within the "natural capital" and "ecosystem services" approaches. Ecosystem services 34:106-112

Gray M (2019) Geodiversity, geoheritage and geoconservation for society. International Journal of Geoheritage and Parks

Gray M Gordon JE, Brown EJ (2013) Geodiversity and the ecosystem approach: the contribution of geoscience in delivering integrated environmental management. Proceedings of the Geologists' Association, 124(4):659-673

Gundersen LC (Ed.) (2018) Scientific integrity and ethics in the geosciences. American Geophysical Union, Wiley, p 336

Hall CM (2019) Constructing sustainable tourism development: the 2030 agenda and the managerial ecology of sustainable tourism. J Sustain Tour 27(7):1044-1060

Kim SS, Kim M, Park J, Guo Y (2008) Cave tourism: tourists' characteristics, motivations to visit, and the segmentation of their behavior. Asia Pacific Journal of Tourism Research 13(3):299-318

Liso IS, Chieco M, Fiore A, Pisano L, Parise M (2020) Underground geosites and caving speleotourism: some considerations, from a case study in southern Italy. Geoheritage 12(1):13

Lobo HAS (2015) Tourist carrying capacity of Santana cave (PETARSP, Brazil): a new method based on a critical atmospheric parameter. Tour Manag Perspect 16:67-75

Lobo HAS, Trajano E, de Alcântara Marinho M, Bichuette ME, Scaleante JAB, Scaleante OAF et al (2013) Projection of tourist scenarios onto fragility maps: framework for determination of provisional tourist carrying capacity in a Brazilian show cave. Tour Manag 35:234-243

Mihailović D, Jovanović S (1997) Praistorijske slikane predstave u pećini Gabrovnica kod Kalne (istočna Srbija). Starinar 48:133-143 (in Serbian)

Mogk DW (2017) Geoethics and professionalism: the responsible conduct of scientists. In Peppoloni,S, Di Capua, G, Bobrowsky, PT, Cronin, VS (Eds.) Geoethics: at the heart of all geosciences. Annals of Geophysics 60, Fast Track 7. https://doi.org/10.4401/ag7584

Mogk DW, Bruckner MZ (2020) Geoethics training in the earth and environmental sciences. Nature Reviews Earth \& Environment 1: 81-83. https://doi.org/10.1038/s43017-020-0024-3

Nepal R, al Irsyad MI, Nepal SK (2019) Tourist arrivals, energy consumption and pollutant emissions in a developing economyimplications for sustainable tourism. Tour Manag 72:145-154

Newsome D, Dowling R (2018) Geoheritage and geotourism. In Geoheritage (pp 305-321). Elsevier

Newsome D, Moore SA, Dowling RK (2012) Natural area tourism: ecology, impacts and management (Vol. 58). Channel view publications: Bristol, UK

Parise, M. (2011). Some considerations on show cave management issues in Southern Italy. In Karst management (pp. 159-167). Springer, Dordrecht.

Parise M, Pascali V (2003) Surface and subsurface environmental degradation in the karst of Apulia (southern Italy). Environ Geol 44(3): 247-256

Peppoloni S, Di Capua G (2012) Geoethics and geological culture: awareness, responsibility and challenges. Annals of Geophysics 55:335-341, ISSN: 2037-416X. https://doi.org/10.4401/ag-6099

Peppoloni S, Di Capua, G (Eds.) (2015) Geoethics: the role and responsibility of geoscientists. Geological Society, London, Special Publications, p 419

Peppoloni S, Di Capua G (2016) Geoethics: ethical, social, and cultural values in geosciences research, practice, and education. In: Wessel G, Greenberg J (Eds.) Geoscience for the public good and global development: toward a sustainable future. Geological Society of America, special paper 520, p 17-21. https://doi.org/10.1130/ 2016.2520(03) 
Peppoloni S, Di Capua G (2017) Geoethics: ethical, social and cultural implications in geosciences. In Peppoloni S, Di Capua G, Bobrowsky PT, Cronin VS (Eds) Geoethics: at the heart of all geosciences. Annals of Geophysics 60, Fast Track 7. https://doi. org/10.4401/ag-7473

Peppoloni S, Di Capua G (2018) Ethics. In: Bobrowsky PT, Marker B (eds) Earth sciences series. encyclopedia of engineering geology. Springer International Publishing, Cham. https://doi.org/10.1007/ 978-3-319-12127-7-115-1

Peppoloni S, Bobrowsky P, Di Capua G (2015) Geoethics: a challenge for research integrity in geosciences. pp. 287-294. https://doi.org/ 10.1142/9789814632393_0035. In: Steneck N, Anderson M, Kleinert S, Mayer T (Eds.) Integrity in the Global Research Arena, World Scientific

Peppoloni S, Bilham N, Di Capua G (2019) Contemporary Geoethics Within the Geosciences. In: Bohle M (ed) Exploring geoethics: ethical implications, societal contexts, and professional obligations of the geosciences. Palgrave Pivot, Cham, p XIV + 214, ISBN 978-3030-12009-2

Romelić J, Tomić P (2002) Održivi turizam u zaštićenim prirodnim predelima Vojvodine. Turizam, 6, 19-22 (in Serbian)

Stamenković I, Lutkić S (2008) Possibilities for the development of ecorural tourism in Bezdan. Researches review of the Department of Geography, Tourism and Hotel Management, University of Novi Sad, Serbia, 37, 56-73. (in Serbian)

Tičar J, Tomić N, Valjavec MB, Zorn M, Marković SB, Gavrilov MB (2018) Speleotourism in Slovenia: balancing between mass tourism and geoheritage protection. Open Geosciences 10(1):344-357

Tomić P, Romelić J, Kicošev S, Stojanović V, Pajović T, Pavlica K, ... Aleksić J (2002) Sustainable tourism. Beograd: Ministry for natural resources and the environmental protection of the Republic of Serbia. (in Serbian)

Tomić N, Antić A, Marković SB, Đorđević T, Zorn M, Valjavec MB (2019) Exploring the potential for Speleotourism development in eastern Serbia. Geoheritage 11(2):359-369

Vuković S, Antić A (2019) Speleological approach for geotourism development in Zlatibor county (West Serbia). Turizam 23(1):53-68

Wilken R (2005) Evolutions of Lascaux. Ashgate Publishing, Farnham

Wyss M, Peppoloni S (Eds.) (2015) Geoethics: ethical challenges and case studies in earth sciences. Elsevier, Waltham, Massachusetts, $p$ 450

Xu S, Sirieix C, Ferrier C, Lacanette-Puyo D, Riss J, Malaurent P (2015) A geophysical tool for the conservation of a decorated cave-a case study for the Lascaux Cave. Archaeol Prospect 22(4):283-292 